\title{
Ground leakage Current Caused by Common-Mode Voltage OF PWM INVERTER
}

Jerzy Ryszard Szymański ${ }^{1}$, Marta Żurek-Mortka ${ }^{2 *}$

${ }^{1}$ Kazimierz Pulaski University of Technology and Humanities in Radom, Faculty of Transport, Electrical Engineering and Computer Science, Malczewski Street 29, 26-600 Radom, Poland, email: j.szymanski@uthrad.pl

${ }^{2}$ Kazimierz Pulaski University of Technology and Humanities in Radom, Faculty of Transport, Electrical Engineering and Computer Science, Malczewski Street 29, 26-600 Radom, Poland, email: m.zurek-mortka@uthrad.pl

"Corresponding author

\section{Reviewed positively: 28.05 .2019}

Information about quoting an article:

Szymański J.R., Żurek-Mortka M. (2019). Ground Leakage Current Caused by Common-Mode Voltage of PWM inverter. Journal of civil engineering and transport. 1(1), 15-25. DOI: 10.24136/tren.2019.002

Abstract - In railway tractive vehicles, three-phase PWM (Pulse Width Modulation) inverters generate parasitic Differential-Mode Voltages (DMV) and Common-Mode Voltages (CMV). Parasitic voltages are a side effect of using the width modulation to shape the phase-to-phase inverter's voltage. In this article, the authors present a mathematical description of the DM and CM voltages and carry out their spectral analysis. Based on the spectral harmonics analysis, the authors present a method for filtration of harmonics of DM and CM voltages aimed at limiting the capacitance parasitic currents: due to DM voltage - phase-to-phase parasitic current and CMvoltage-ground parasitic currents. As the final result of the tests, almost complete elimination of leakage parasitic current form PE shock protection system was achieved.

Keywords - common-mode voltage, differential-mode voltage, PWM modulation, three-phase traction voltage inverter, twolevel PWM inverter

\section{INTRODUCTION}

Ground currents of high frequency disturbances are caused by the common-mode voltage (CM) $\mathrm{u}_{\mathrm{am}}$ of the inverter. The basic harmonic of this voltage has the frequency resulting from the switching frequency of the inverter's semiconductor valves. In industrial applications, the capacitive ground leakage current forced by the $\mathrm{CM}$ voltage of the inverter flows to the transformer in the TN (ang. ground-neutral) system through a grounded sta connection of the secondary windings. In IT (ang. isolationground) system (or High Resistance Grounded network HGR) of the industrial power supply system the ground leakage current flows through the parasitic capacitances between the ground and the ungrounded star connection of the transformer's secondary windings. In an industrial power system with an IT transformer network type, the CM voltage of the inverter, which is deposited on the parasitic capacitances between the ground and the ungrounded star connection of the secondary windings of the transformer causes high frequency disturbances of voltages in transformer. In that case the CM voltage of the inverter adds to the phase voltages of the transformer.

In DC voltage traction network, the voltage inverters in auxiliary equipment drives (traction substations, railway stations) are powered by the industrial power network therefore the analysis of parasitic phenomena is the same as for industrial inverter drives. Analysis of the dissemination of parasitic capacitive ground leakage current arising from $\mathrm{CM}$ voltage of traction inverters of the main locomotive drives must take into account the grounding of the negative pole of the drive locomotive inverter and the grounding of the negative rectifier's pole in the traction substation. The analysis of $\mathrm{CM}$ and DM voltage is complex and requires a thorough research [1].

Two-level voltage PWM inverters are commonly used for supplying three-phase induction motors in industrial lowvoltage networks and for traction motors in the $D C$ and $A C$ railway traction. Lack of effective methods for reducing the negative impact of parasitic CM and DM voltages is the cause for increased risk of fault to loads powered from a common transformer [2-3]. In addition, there is risk of electric shock related to the leakage current caused by the $\mathrm{CM}$ voltage in inverters. During the operation of motors in a potentially explosive zone, the earth leakage current can cause sparking, provoking an explosion even if the motor's rotor speed is near zero.

The literature describes the cases of damage to converters due to leakage currents caused by the $\mathrm{CM}$ and DM voltages [2]. A variety of methods have been proposed in literatures [4-8] to address the CM and DM noise problem and its related issues. The exact $\mathrm{CM}$ and DM equivalent 
circuits of PWM inverter in drive systems derived by taking the rectifier into account was presented in [9]. Besides, an improved LCL filter using in transformer-less three-leve photovoltaic inverter system for leakage current suppression was presented in [10]. The minimization of current harmonics in an alternating voltage grid is discussed in the literature [11-12].

This paper is organized as follow: the first two parts is about the mathematical and analytical description of $\mathrm{CM}$ and DM voltages of the inverter. The next part is about the studies on the CM and DM voltage of the inverter using analytical and computer methods and verified then by the experimental results. In the final part of paper, a power supply system for the traction drive was proposed, in which high frequency disturbance currents created as a result of $\mathrm{CM}$ and DM voltage by PWM inverters were eliminated.

\section{Mathematical Description of a Linear Three-Phase INVERTER MODEL}

The transformation of DC voltage into single-phase and three-phase $A C$ voltage, with the use of the powerelectronic PWM inverter has side effects such as the $\mathrm{CM}$ voltages $[9,13]$. In this chapter, the mathematical relations describing the voltage of the common mode disturbances were derived bases on the description of the three-phase linear model of PWM inverter. The three-phase two-leve traction inverter is shown in Figure 1. It consists of three identical branches of half-bridges in each phase and this three-phase system is symmetrical for individual harmonics. In modeling and analyzing the inverter, a three-phase notation is used $[1,14]$.

On the basis of the description of the three-phase inverter, a mathematical relationship is determined describing the $\mathrm{CM}$ voltage of the inverter with the grounded negative rail of DC voltage supply (traction inverters) and without galvanic ground of the power-electronic elements (industrial inverters and auxiliary railway equipment inverters) $[1,14]$.

The output phase-to-phase voltages of the inverter are described by (1):

$$
\begin{aligned}
& \mathrm{u}_{\mathrm{AB}}=\mathrm{u}_{\mathrm{AG}}-\mathrm{u}_{\mathrm{BG}} \\
& \mathrm{u}_{\mathrm{BC}}=\mathrm{u}_{\mathrm{BG}}-\mathrm{u}_{\mathrm{CG}} \\
& \mathrm{u}_{\mathrm{CA}}=\mathrm{u}_{\mathrm{CG}}-\mathrm{u}_{\mathrm{AG}}
\end{aligned}
$$

where: $\mathrm{u}_{\mathrm{AG}}, \mathrm{u}_{\mathrm{BG}}, \mathrm{u}_{\mathrm{CG}}$ are instantaneous voltages, which satisfy the condition (2):

$$
\mathrm{u}_{\mathrm{AB}}+\mathrm{u}_{\mathrm{BC}}+\mathrm{u}_{\mathrm{CA}}=0
$$

If the load neutral point $\mathrm{N}$ is not connected to the reference point $\mathrm{G}$ on the DC voltage side (Fig. 1), the phase voltages can be expressed as (3):

$$
\begin{aligned}
& \mathrm{u}_{\mathrm{AN}}=\frac{1}{3}\left(2 \mathrm{u}_{\mathrm{AG}}-\mathrm{u}_{\mathrm{BG}}-\mathrm{u}_{\mathrm{CG}}\right) \\
& \mathrm{u}_{\mathrm{BN}}=\frac{1}{3}\left(-\mathrm{u}_{\mathrm{AG}}+2 \mathrm{u}_{\mathrm{BG}}-\mathrm{u}_{\mathrm{CG}}\right) \\
& \mathrm{u}_{\mathrm{CN}}=\frac{1}{3}\left(-\mathrm{u}_{\mathrm{AG}}-\mathrm{u}_{\mathrm{BG}}+2 \mathrm{u}_{\mathrm{CG}}\right)
\end{aligned}
$$

By describing the switching states of inverter $S_{A}, S_{B}, S_{C}$ with 0 and 1 (e.g. $S_{A}=1$, indicates the state in which the transistor in phase $A$ is switched on, and $S_{A}=0$, when the lower transistor in phase $A$ is switched off) the output phaseto-phase voltages can be presented as follows (4):

$$
\begin{aligned}
& \mathrm{u}_{\mathrm{AB}}=\mathrm{U}_{\mathrm{d}}\left(\mathrm{S}_{\mathrm{A}}-\mathrm{S}_{\mathrm{B}}\right) \\
& \mathrm{u}_{\mathrm{BC}}=\mathrm{U}_{\mathrm{d}}\left(\mathrm{S}_{\mathrm{B}}-\mathrm{S}_{\mathrm{C}}\right) \\
& \mathrm{u}_{\mathrm{CA}}=\mathrm{U}_{\mathrm{d}}\left(\mathrm{S}_{\mathrm{C}}-\mathrm{S}_{\mathrm{A}}\right)
\end{aligned}
$$

Similarly for a symmetrical load the phase voltages are expressed by (5):

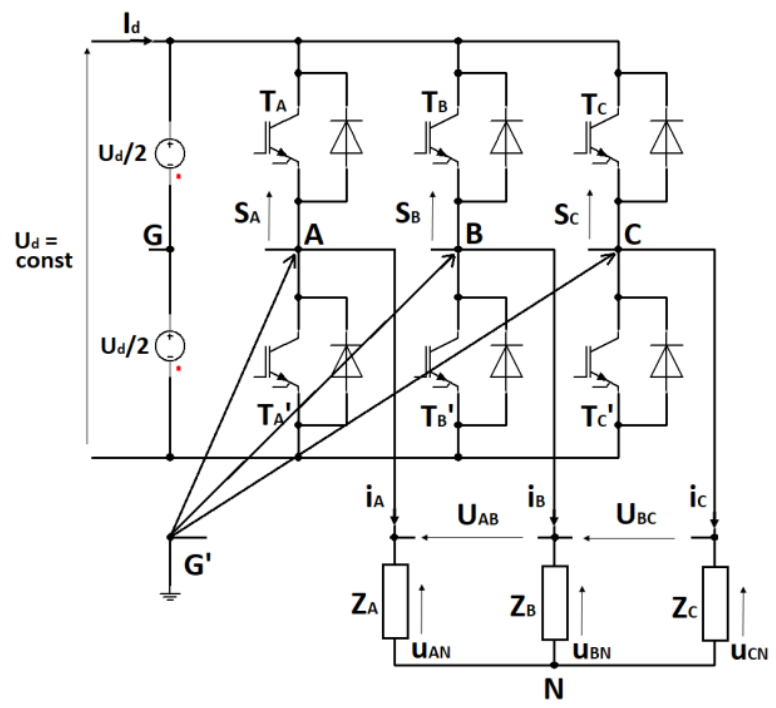

Fig. 1. Three-phase two-level traction inverte 


$$
\begin{aligned}
& \mathrm{u}_{\mathrm{AN}}=\frac{\mathrm{U}_{\mathrm{d}}}{3}\left(2 \mathrm{~S}_{\mathrm{A}}-\mathrm{S}_{\mathrm{B}}-\mathrm{S}_{\mathrm{C}}\right) \\
& \mathrm{u}_{\mathrm{BN}}=\frac{\mathrm{U}_{\mathrm{d}}}{3}\left(-\mathrm{S}_{\mathrm{A}}+2 \mathrm{~S}_{\mathrm{B}}-\mathrm{S}_{\mathrm{C}}\right) \\
& \mathrm{u}_{\mathrm{AN}}=\frac{\mathrm{U}_{\mathrm{d}}}{3}\left(-\mathrm{S}_{\mathrm{A}}-\mathrm{S}_{\mathrm{B}}+2 \mathrm{~S}_{\mathrm{C}}\right)
\end{aligned}
$$

If the $G$ point is grounded in Figure 1 , then the $U_{N G}$ voltage is

$$
\mathrm{u}_{\mathrm{AG}}+\mathrm{u}_{\mathrm{BG}}+\mathrm{u}_{\mathrm{CG}}=\mathrm{u}_{\mathrm{AN}}+\mathrm{u}_{\mathrm{BN}}+\mathrm{u}_{\mathrm{CN}}+3 \mathrm{u}_{\mathrm{NG}}
$$

Since $u_{A G}+u_{B G}+u_{C G}=0$, the $C M$ voltage $u_{N G}$ of inverter is determined by (8):

$$
\mathrm{u}_{\mathrm{NG}}=\frac{\mathrm{u}_{\mathrm{AN}}+\mathrm{u}_{\mathrm{BN}}+\mathrm{u}_{\mathrm{CN}}}{3}
$$

The relation (8), CM voltage of inverter is equal to voltage with respect to another ground point, e.g. G' (Fig.1), which is not galvanically connected to the inverter's electrical circuit (e.g. relative to the protective PE ground of the drive system). However, if the ground potential point $\mathrm{G}^{\prime}$ is shorted with the negative DC voltage bus, as in the traction inverters supplied with the DC traction's network, then according to Figure 1 the voltage $\mathrm{U}_{\mathrm{G}} \mathrm{G}^{\prime}=\mathrm{U}_{\mathrm{d}} / 2$ and then the following applies (9) [14]:

$$
\mathrm{u}_{\mathrm{NG}}=\mathrm{u}_{\mathrm{NG}}+\mathrm{u}_{\mathrm{GG}}=\mathrm{u}_{\mathrm{NG}}+\frac{\mathrm{U}_{\mathrm{d}}}{2}
$$

After taking into account (9) and the voltage from equations (6), a dependency considering the sum is obtained (10):

$$
\mathrm{u}_{\mathrm{NG}}=\frac{\mathrm{u}_{\mathrm{AN}}+\mathrm{u}_{\mathrm{BN}}+\mathrm{u}_{\mathrm{CN}}}{3}+\frac{1}{2} \mathrm{U}_{\mathrm{d}}
$$

From (10) a conclusion can be drawn that the grounding of the negative DC voltage bus of the inverter (i.e. like as in

Phase voltages of inverter can be described by (11)

$$
\begin{gathered}
\mathrm{u}_{\mathrm{iG}}(\mathrm{t})=\frac{\mathrm{U}_{d}}{2}+\frac{\mathrm{U}_{d}}{2} \mathrm{M} \\
\cos \left(\omega_{0} \mathrm{t}+\theta_{\mathrm{i}}\right)+\frac{2 \mathrm{U}_{d}}{\pi} \sum_{\mathrm{m}=1}^{\infty} \frac{1}{\mathrm{~m}} \mathrm{~J}_{0}\left(\mathrm{~m} \frac{\pi}{2} \mathrm{M}\right) \sin \left((\mathrm{m}+\mathrm{n}) \frac{\pi}{2}\right) \cdot \cos \left(\mathrm{m} \omega_{\mathrm{c}} \mathrm{t}+\mathrm{n}\left(\omega_{0} \mathrm{t}+\theta_{\mathrm{i}}\right)\right)+ \\
+\frac{2 \mathrm{U}_{d}}{\pi} \sum_{\substack{\mathrm{m}=1 \\
\mathrm{n}}}^{\infty} \sum_{\substack{\mathrm{n}=-\infty \\
\mathrm{n} \neq 0}}^{\infty} \frac{1}{\mathrm{~m}} \mathrm{~J}_{\mathrm{n}}\left(\mathrm{m} \frac{\pi}{2} \mathrm{M}\right) \cdot \sin \left((\mathrm{m}+\mathrm{n}) \frac{\pi}{2}\right) \cos \left(\omega_{0} \mathrm{t}+\theta_{\mathrm{i}}\right)
\end{gathered}
$$

where:

$\mathrm{i}-\mathrm{A}, \mathrm{B}, \mathrm{C}$,

$\theta-0,2 / 3 \pi,-2 / 3 \pi$ - voltages and angles of individual phases of the source respectively,

$\mathrm{J}_{\mathrm{n}}(\mathrm{x})$ - Bessel function of the $\mathrm{n}$-th order with the argument $\mathrm{x}$

$\mathrm{M}$ - PWM modulation factor,

$m$-index of row of harmonic carrier frequency $f_{c}$,

$\mathrm{n}$-index of row of harmonic frequency modulating of inverter $\mathrm{f}_{\mathrm{o}}$,

$\omega_{0}-$ frequency of the fundamental (modulating) harmonic,

$\omega_{\mathrm{c}}-$ frequency of the carrier waveform (modulated) of PWM modulation.

In the phase voltages there are no harmonics of even The CM voltage of the PWM inverter is described by (8). $\mathrm{m} \pm \mathrm{n}$ combination, because they are eliminated by the factor After transformations, the mathematical description of the $\sin ((m+n) \pi / 2)$. These harmonics are also not present in equation (8) in the form of equation is obtained (12). The CM phase-to-phase voltages.

voltage of the $\mathrm{u}_{\mathrm{cm}}$ inverter takes the form:

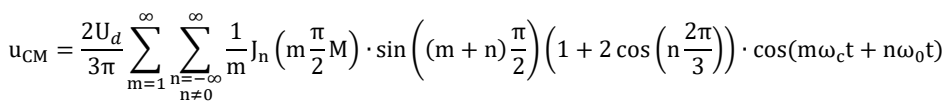

Correct understanding of the complexity of influence of phase voltages of inverter on voltages: differential-mode DM (phase-to-phase) and common-mode CM (ground), facilitates the procedure proposed in [16] consisting in decomposition of the inverter phase voltage spectrum into spectra of differentials DM and CM inverter's voltages which 
will be subject of analysis in section 4 of the article.

Taking into account the symmetry of a three-phase system for individual harmonics, the expressions describing

The inverter's phase-to-phase voltage is described by (13):

voltages in phase-to-phase voltages can be obtained directly from the phase-to-phase voltages equation.

$$
\begin{aligned}
u_{i j}(t)=u_{i N}(t)-u_{j N}(t)= & \sqrt{3} U_{d} M \cos \left(\omega_{0} t+\frac{\pi}{6}+\theta_{i}\right)+\frac{4 U_{d}}{\pi} \sum_{\substack{m=1 \\
n=-\infty}}^{\infty} \sum_{\substack{n \neq 0 \\
n \neq 0}}^{\infty} \frac{1}{m} J_{n}\left(m \frac{\pi}{2} M\right) \cdot \\
& \cdot \sin \left((m+n) \frac{\pi}{2}\right) \sin \left(n \frac{\pi}{3}\right) \cdot \cos \left(m \omega_{c} t+n\left(\omega_{0} t-\frac{\pi}{3}\right)+\frac{\pi}{2}+\theta_{i}\right)
\end{aligned}
$$

where:

$\mathrm{ij}=\mathrm{AB}, \mathrm{BC}, \mathrm{CA}$.

Then the inverter's DM voltages for the individual pairs of the inverter voltage phases are described by (14):

$$
\mathrm{u}_{\mathrm{DM}}=\frac{4 \mathrm{U}_{d}}{\sqrt{3 \pi}} \sum_{\mathrm{m}=1}^{\infty} \sum_{\mathrm{n}=-\infty}^{\infty} \frac{1}{\mathrm{~m}} \mathrm{~J}_{\mathrm{m}}\left(\mathrm{m} \frac{\pi}{2} \mathrm{M}\right) \cdot \sin \left((\mathrm{m}+\mathrm{n}) \frac{\pi}{2}\right) \sin \left(\mathrm{n} \frac{\pi}{3}\right) \cos \left(\mathrm{m} \omega_{\mathrm{c}} \mathrm{t}+\mathrm{n} \omega_{0} \mathrm{t}\right)
$$

To explain the formation of CM and DM voltage of PWM inverter, a model of three-phase two-level voltage inverter shown in Figure 2 is used. There is an electrical scheme of a two-level three-phase inverter, which allows time and frequency analysis of inverter voltages for freely adopted PWM modulation parameters. Through simulation the CM voltage of inverter $u_{c m}$ is described by equation (8).

As a result of the simulation, the common-mode voltages for basic harmonic of phase voltage equal to $50 \mathrm{~Hz}$ were obtained, with two totally different factors of modulation $\mathrm{M}=0.9$ and $\mathrm{M}=0.1$ (Fig. 3). A sinusoidal modulator of the phase voltage of the PWM inverter is used, in which the frequency of the modulated waveform is 500 $\mathrm{Hz}$. It has been assumed that the modulation frequency can range from $0.5 \mathrm{~Hz}$ to $50 \mathrm{~Hz}$ - it applies to constant torque on the motor shaft. The carrier frequency of a sinusoidal PWM modulation in inverters with IGBT transistors is from $2 \mathrm{kHz}$ to $15 \mathrm{kHz}$. To the tests assume the values of carrier frequency equal to $500 \mathrm{~Hz}, 1 \mathrm{kHz}$ and $2 \mathrm{kHz}$. Based on the simulation results (Fig. 4), it should be noted that the shape of the voltage of common-mode waveform depends on the modulation factor $\mathrm{M}$, and therefore also depends on it spectrum of harmonic components.

The effective value of the inverter's common-mode voltage $u_{\mathrm{cm}}$ as a function of the PWM modulation factor $M$ was determined through the sinusoidal modulating voltage. In the calculations, the electrical scheme of the PWM modulator model shown in Figure 2 (PWM control) is
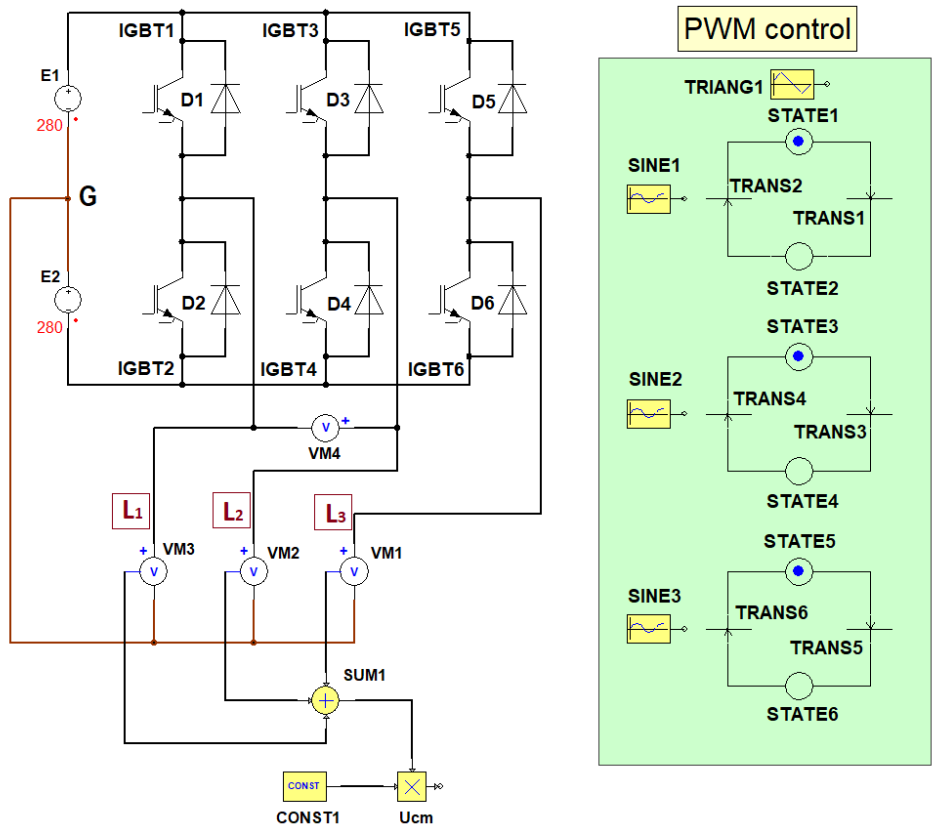

Fig. 2. Circuitry model of the inverter: $u_{\mathrm{ph}}$ phase voltage, $u_{\mathrm{ph}-\mathrm{ph}}$ phase-to-phase voltage and DM voltage $\mathrm{u}_{\mathrm{DM}}$ and $C \mathrm{CM}$ voltage $\mathrm{u}_{\mathrm{CM}}$ 
applied, in which the carrier triangular waveform has the frequency $f_{c}=1 \mathrm{kHz}$ (TRIANG1). The results of the calculations are presented graphically in Figure 4 , where the effective value of the $\mathrm{CM}$ voltage $\mathrm{u}_{\mathrm{cm}}$ is determined with respect to half of the $D C$ voltage supply of the inverter $U_{d} / 2$. $\mathrm{U}_{\mathrm{CM}} /\left(\mathrm{U}_{\mathrm{d}} / 2\right)[\%]$

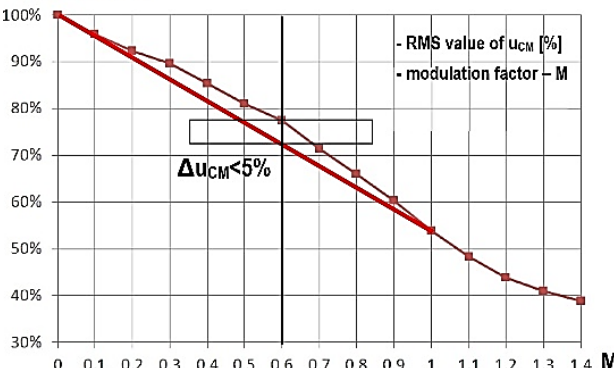

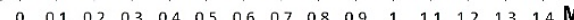

Fig. 3. Share of effective value (RMS) of inverter's CM voltage $u_{\mathrm{cm}}$ with PWM sine modulation as a function of the modulation factor $\mathrm{M}$ [14]

For the coefficient in the range from $M=0$ to $M=1.4$ the approximate effective value of the inverter's commonmode voltage can be designated from Figure 3. This graph shows its percentage share in relation to half of the DC power voltage supply $U_{d}$ of the inverter. Based on Figure 3 it can be adopted that for $M=1$, the effective value of the inverter's common-mode voltage is $1 / 4 U_{d}$, and for $M$ which is close to zero, it is $1 / 2 U_{d}$

A characteristic feature of the inverter's $\mathrm{CM}$ voltage $\mathrm{u}_{\mathrm{c}}$ is the square shape with frequency $f_{c}$ the modulation factor M close to zero, i.e. during the generation of basic harmonic of phase-to-phase voltages of the inverter with the effective values close to zero (Fig. 4d)

For example, a cage induction motor powered by an inverter does not generate drive torque even though the inverter's phase voltages have an effective value equal to half the DC voltage supplying of inverter $U_{d} / 2$ in referred to ground. The motor is affected by narrow rectangular pulses of phase-to-phase voltages of inverter. Tapering phase-tophase voltages impulses arise due to the disappearance of the angle of shifts between the phase voltages of individual phases.

The $\mathrm{CM}$ voltage of inverter $\mathrm{u}_{\mathrm{CM}}$, for phase voltages of inverter with rectangular waveform and amplitude equal to $\mathrm{U}_{\mathrm{d}} / 2$ (Fig. $4 \mathrm{~b}, \mathrm{M}$ close to zero), is a rectangular waveform with the frequency $f_{c}$. This creates a danger for human electroshock due to the presence of high frequency $\mathrm{CM}$ voltage with an effective value being $100 \%$ higher than if the inverter is operating with a modulation factor equal to $M=1$ (Fig. 3). With the occurrence of a rectangular waveform of inverter's $\mathrm{CM}$ voltage at $\mathrm{M}=0$, its amplitude spectrum will consist only of the odd harmonics. The harmonics $h_{k}$ have only odd rows: $k=1,3,5,7,9 \ldots=2 n-1$.

\section{Simulation AND EXPERIMENTAL RESEARCH ON THE IN- FLUENCE of CM Voltage on GRound Leakage CuRRent}

In the Polish 3kW DC electrical traction supply system the negative pole of the traction substation's rectifier is shorted through the rail system with the negative pole of the DC voltage of the tractions inverters. The scheme of power supply of auxiliary railway devices is shown in Figure 5 . It is a drive system with a single voltage frequency converter and a squirrel cage motor.

The motor is connected to the voltage inverter of the frequency converter with a three-phase shielded motor cable. In the drive model shown in Figure 5, the parasitic ground leakage current flows through the ground capacitance of the cable and motor, flowing into the inverter through two circuits: through the EMC ground filter of the intermediate circuit and through the transformer's secondary windings working in TN power supply system. The capacitance of the intermediate circuit EMC filter have a small value, typically $0.22 \mu \mathrm{F}-0.35 \mu \mathrm{F}$, so a significant part of this current flows through the secondary windings of the transformer. Capacitive ground leakage current measured in the protective PE conductor on the stretch between the transformer and the EMC filter of the drive frequency converter, caused by the $\mathrm{CM}$ voltage of the inverter $\mathrm{Ucm}_{\mathrm{c}}$, is shown in Figure 6.

The ground leakage current presented in Figure 6a were obtained in simulation tests of the model shown in Figure 2, with the switching frequency of the inverter switches equal to $2 \mathrm{kHz}$. This is the frequency of the triangular waveform modulated by three sinusoidal signals used in the classic sinusoidal PWM. The example result of experimental research is presented in Figure $6 \mathrm{~b}$.

The obtained results show that despite the use of an EMC filter built in the drive frequency converter a significant part of the ground leakage current is flowing through the transformer secondary windings with the TN power network system causing undesirable deformations of the transformer voltages at the common point connection (PCC) of other loads. The inverter's switching frequency has a fundamental harmonic of the inverter's common-mode voltage, here $2 \mathrm{kHz}$. The parasitic DM voltage contains harmonics, which are placed around a multiple of the switching frequency $(2 \mathrm{kHz})[14]$

\section{Frequency AnAlysis of INVERTER's Common-MOde VolTAGE}

Using specialized computer software for the simulation of inverter (Simplorer), the authors analysed the harmonics spectrum of the phase voltages of the three phase inverter shown in Figure 2. The amplitudes and phases of the consecutive five significant higher harmonics are shown in Table 1. The fundamental harmonic has the frequency of $25 \mathrm{~Hz}$ Table 1 shows that the amplitude of the basic harmonic is near $140 \mathrm{~V}$ and its phase angle is almost $360^{\circ}$. The CM voltage of inverter that causes ground leakage current contains a harmonic with frequency of $2 \mathrm{kHz}$ (the frequency of the triangular modulated signal). The remaining harmonics (from 2 to 5 ), are due to the DM voltage, which distorts the phase-to-phase voltage of the inverter. Table 1 does not show higher harmonics of $\mathrm{CM}$ voltage, because of their small amplitudes. 

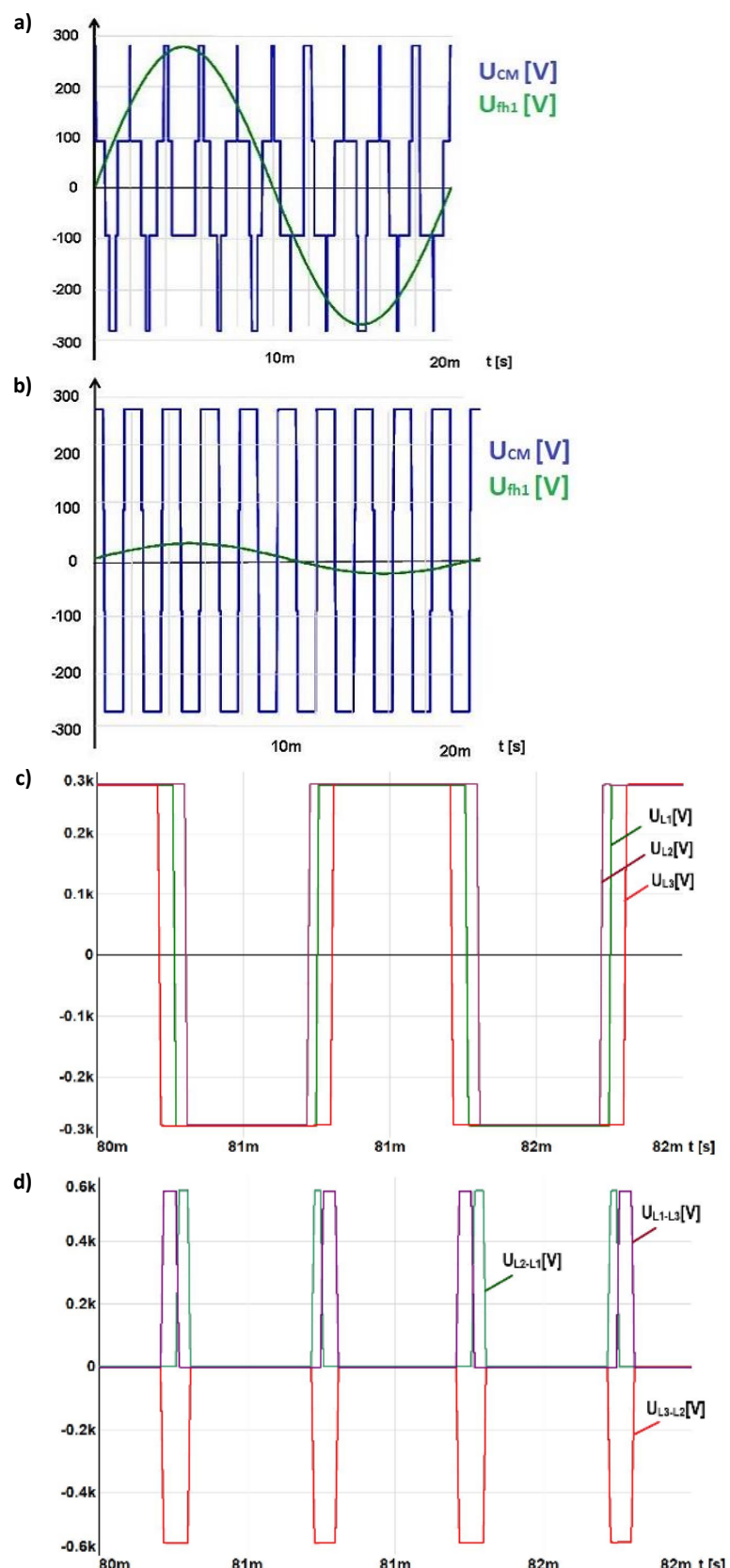

Fig. 4. The inverter's common-mode voltage $u_{c m}$ with sinusoidal modulation method of output voltages $\left(f_{h 1}=50 H z, f_{c}=0.5 \mathrm{kHz}\right.$ (TRIANG1)) and inverters phase and phase-to-phase voltages $\left(f_{h 1}=50 \mathrm{~Hz}, f_{c}=1.0 \mathrm{kHz}\right.$ (TRIANG1)):

a) the $\mathrm{CM}$ voltage $\mathrm{u}_{\mathrm{cM}}$ and 1-harmonic of phase output voltage of the inverter at the modulation factor $\mathrm{M}=0.9\left(\mathrm{f}_{\mathrm{c}}=0.5 \mathrm{kHz}\right)$, b) the $\mathrm{CM}$ voltage $\mathrm{u}_{\mathrm{CM}}$ and 1-harmonic of phase output voltage of the inverter at the modulation factor $M=0.1\left(\mathrm{f}_{\mathrm{c}}=0.5 \mathrm{kHz}\right)$, c) inverter phase voltages for $M=0.1\left(f_{c}=1 \mathrm{kHz}\right)$ d) phase-to-phase voltages for $M=0.1\left(f_{c}=1 \mathrm{kHz}\right)$. 
Table 1. Higher harmonics of phase voltage $u_{p h}$ of inverter with $25 \mathrm{~Hz}$ fundamental harmonic: No. 0 - fundamental harmonic, No. 1 harmonic of $\mathrm{CM}$ voltage, No. 2 - 5 harmonics of $\mathrm{DM}$ voltage

\begin{tabular}{|c|c|c|c|c|}
\hline & $\mathrm{f}[\mathrm{Hz}]$ & $\mathbf{u}_{\text {ph }}[\mathbf{V}]$ & $\theta[\mathrm{deg}]$ & $\%(\max )$ \\
\hline minimum & 25 & 50.214 & 81.209 & 16.604 \\
\hline maximum & $6.05 \mathrm{k}$ & 302.41 & 359.69 & 100 \\
\hline 0 & 25 & 139.52 & 359.69 & 46.136 \\
\hline 1 & $\mathbf{2 k}$ & 302.41 & 81.209 & 100 \\
\hline 2 & $3.975 \mathrm{k}$ & 98.981 & 342.5 & 32.73 \\
\hline 3 & $4.025 \mathrm{k}$ & 100.91 & 161.82 & 33.369 \\
\cline { 1 - 3 } & $5.95 \mathrm{k}$ & 50.214 & 244.66 & 16.604 \\
\hline 4 & $6.05 \mathrm{k}$ & 50.233 & 243.04 & 16.611 \\
\hline 5 & & & & \\
\end{tabular}

Table 2. Higher harmonics of the phase-to-phase voltage $u_{\mathrm{phph}}$ of inverter with $25 \mathrm{~Hz}$ fundamental harmonic: No. 0 - fundamental harmonic, No. 1 - 5 harmonics of DM disturbances

\begin{tabular}{|c|c|c|c|c|}
\hline & $\mathrm{f}[\mathrm{Hz}]$ & $u_{p h-p h}[V]$ & $\theta$ [deg] & $\%(\max )$ \\
\hline minimum & 25 & 46.172 & 33.456 & 19.066 \\
\hline maximum & $10.05 k$ & 242.17 & 312.39 & 100 \\
\hline 0 & 25 & 242.17 & 150.21 & 100 \\
\hline 1 & $3.975 \mathrm{k}$ & 172.16 & 192.30 & 71.09 \\
\hline 2 & $4.025 \mathrm{k}$ & 175.25 & 312.39 & 72.364 \\
\hline 3 & $5.95 \mathrm{k}$ & 85.256 & 33.456 & 35.205 \\
\hline 4 & $6.05 \mathrm{k}$ & 85.292 & 94.028 & 35.219 \\
\hline 5 & $10.05 \mathrm{k}$ & 46.172 & 255.48 & 19.066 \\
\hline
\end{tabular}

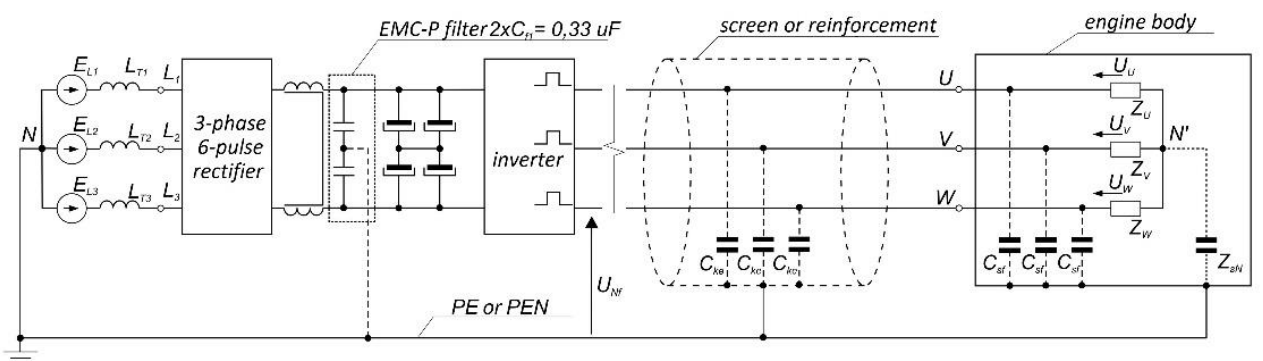

Fig. 5. The model of the drive system with the frequency converter and the parasitic ground capacitances of the shielded cable and the motor

a)
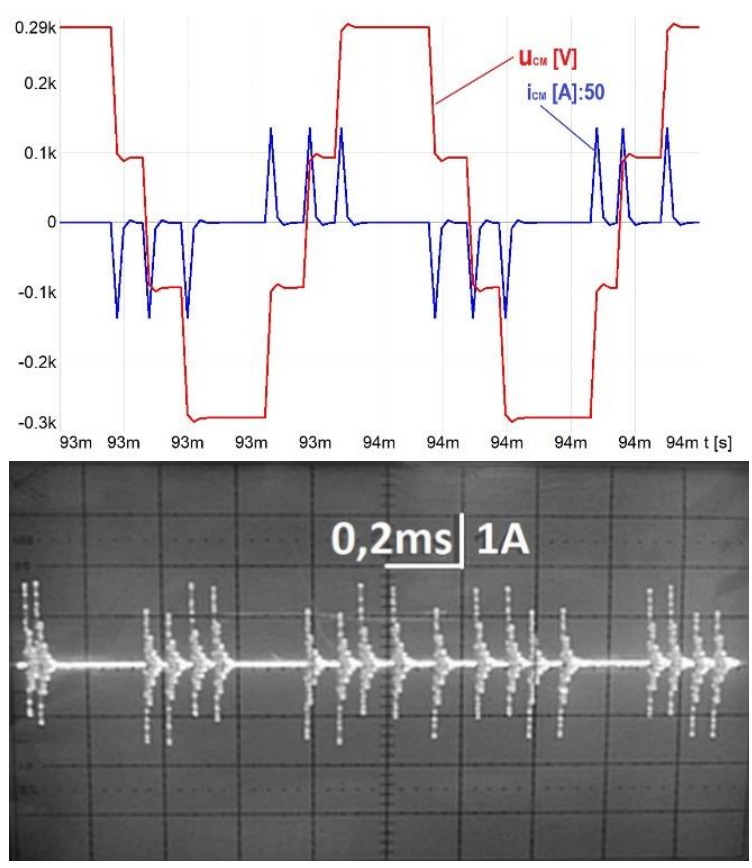

Fig. 6. The example of parasitic ground leakage current forced by the $\mathrm{CM}$ voltage of inverter: a) the result of the simulation tests of the model, b) the test result on the test stand. 
The harmonics of inverter's DM voltage in the phase-tophase voltages of the inverter are shown in Table 2 (No. 1-5). It shows that the amplitude of the basic harmonic of phase-to-phase voltage $u_{\text {ph-ph }}$ at frequency $25 \mathrm{~Hz}$ is greater than the amplitude of the phase voltage $\mathrm{uph}_{\mathrm{ph}}$ and is (15):

$\mathrm{u}_{\mathrm{ph}-\mathrm{ph}}=\sqrt{3} \cdot \mathrm{u}_{\mathrm{ph}}=\sqrt{3} \cdot 140 \mathrm{~V}=242 \mathrm{~V}$

The amplitude of the basic harmonic dominates in relation to the harmonic amplitudes of the differential-mode voltage, which are arranged as sidebands at even and odd multiples of the frequency of the modulated voltage $f_{c}$ of PWM [14]

The task of commercial three-phase sinusoidal LC motor filters is to filter differential harmonics from the moto phase-to-phase voltage [14]. The fundamental harmonic of drive inverters are usually in the range from $0.5 \mathrm{~Hz}$ to $50 \mathrm{~Hz}$ (the motor work zone with constant torque). The use of sinusoidal LC motor filters shapes the phase-to-phase voltages to the sine wave, thus reducing the steepness of the $\mathrm{du} / \mathrm{dt}$ voltage rise on the stator windings, thereby increasing the motor's windings insulation life. The motor sine-wave filter LC eliminates harmonics of DM voltage of inverter from the motor supply. As presented in Table 2, the harmonics of the DM voltage distorts the sinusoidal shape of the phaseto-phase voltage of the inverter. The harmonics are grouped at even and odd multiples of the modulated waveform frequency, here the triangular waveform at the frequency $f_{c}$ $=2 \mathrm{k} \mathrm{Hz}$. These are harmonics marked as 1-5 in Table 2 and 2-5 in Table 1.

After discussing decomposition of the amplitude-phase spectrum of phase voltage of the inverter $u_{\mathrm{ph}}$ (Table 1 ) to the DM voltage components (phase-to-phase disturbances

a)

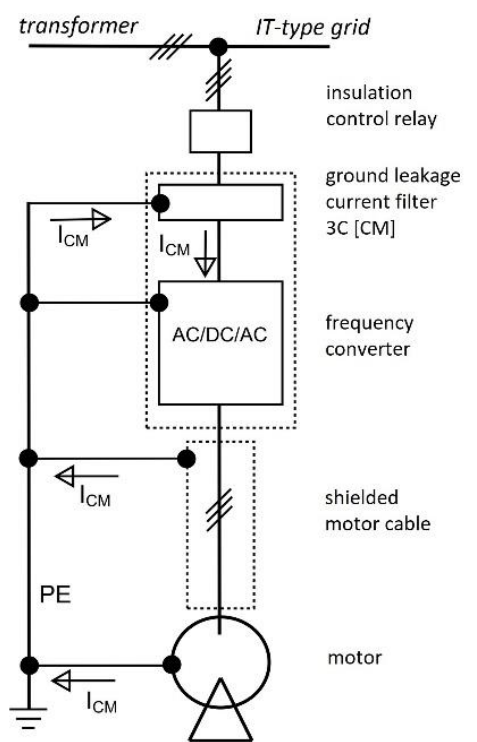

harmonics) (Table 2), the analysis of spectrum of CM voltage which evokes the parasitic ground current - capacitive leakage current will be conducted. The harmonics of the lower frequencies of the amplitude-phase spectrum of the ground disturbances voltage ucm of inverter are presented in Table 3. As can be seen in Table 3, harmonics of the CM voltage of the inverter are located close to the multiples of the carrier frequency $f_{c}$ of the PWM. The inverter's fundamental harmonic of the $\mathrm{CM}$ voltage has a frequency equal to the carrier frequency waveform $\mathrm{f}_{\mathrm{c}}$ of the PWM, which is also the switching frequency of the controlled semiconductor power elements of inverter - the IGBT transistors. The harmonics of CM voltages ucm have the same amplitude and phase in all three phases of the inverter and are called "zero components". Only the basic harmonic $\left(f_{c}=2 \mathrm{kHz}\right)$ of the $\mathrm{CM}$ voltage of inverter $\mathrm{uam}$ is shown (Table 1 - item 1). The remaining harmonics (Table 3) have frequencies beyond the range of the next five harmonics shown in the phase voltage spectrum of the inverter $u_{p h}$.

Table 3. Higher harmonics of $\mathrm{CM}$ voltage $\mathrm{u}_{\mathrm{CM}}$ of the drive inverter with a fundamental harmonic of $25 \mathrm{~Hz}$

\begin{tabular}{|c|c|c|c|c|}
\hline & $\mathrm{f}[\mathrm{Hz}]$ & $\mathrm{u}_{\mathrm{CM}}[\mathrm{V}]$ & $\theta[\mathrm{deg}]$ & $\%$ (max) \\
\hline minimum & $2 \mathrm{k}$ & 22.501 & 81.118 & 7.4243 \\
\hline maximum & $12.075 \mathrm{k}$ & 303.08 & 325.3 & 100 \\
\hline 0 & $2 \mathrm{k}$ & 303.08 & 81.118 & 100 \\
\hline 1 & $7.925 \mathrm{k}$ & 29.297 & 143.62 & 9.6664 \\
\hline 2 & $8.075 k$ & 28.763 & 325.3 & 9.4902 \\
\hline 3 & $10 \mathrm{k}$ & 26.755 & 253.4 & 8.8278 \\
\hline 4 & $11.925 \mathrm{k}$ & 22.501 & 307.45 & 7.4243 \\
\hline 5 & $12.075 \mathrm{k}$ & 23.898 & 128.2 & 7.8851 \\
\hline
\end{tabular}

b)

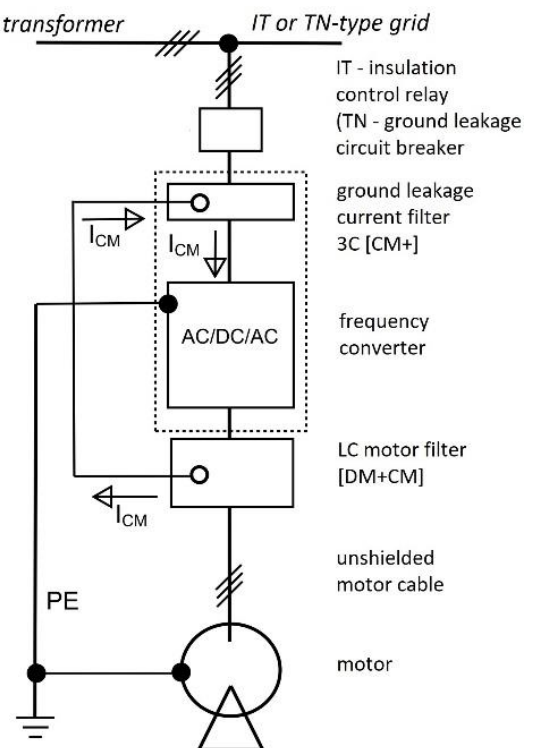

Fig. 7. Power system of the motor drive with frequency converter, where $\mathrm{I}_{\mathrm{CM}}$ is the capacitive leakage current due to the $\mathrm{CM}$ voltage of the inverter: a) with capacitive filter, b) with patented DM + CM filter [15] 
The sine wave motor voltages LC filter, which filters the harmonics of DM voltage from the phase-to-phase voltages of the motor, does not filter the harmonics of the inverter's CM voltage [15]. Proposed commercial LC filter of DM voltage for small and medium power drives requires insertion of motor chokes into the motor current path. Interrupting the motor current path, in particular in highpower drives, is not a commonly used engineering practice. Known negative effects of bearing currents of the motor, or ground currents flown through the rotors of pump motors submerged in water, are not suppressed by commercial LC sine waves filters, because the capacitive ground leakage currents is caused by the $\mathrm{CM}$ voltage $\mathrm{ucm}_{\mathrm{cm}}$ of the inverter.

\section{Methods for Limiting Parasitic Ground Leakage \\ CURRENTS Generated By CM Voltage OF INVERTERS}

For high power drives with frequency converter, the authors propose supplying the drive from an IT network system (or High Resistance Grounded HRG network). The IT type system eliminates the galvanic shorting of the transformer's windings with ground and thus the ground current is limited. Thus it flows only through the parasitic ground capacitance on the secondary side of the transformer supplying the frequency converter. The ground leakage current from the transformer can be completely eliminated by using an external additional capacitive filter. Here it is possible to connect an additional circuit in which ground leakage current flowing to the inverter is bypassing the transformer (Fig. 7a). For the complete elimination of ground leakage currents from the PE protective conductor and the transformer and to eliminate the differential-mode voltage from the motor phase-to-phase voltages, the power supply system shown in Figure $7 \mathrm{~b}$ may be used.

The use of $\mathrm{DM}$ and $\mathrm{CM}$ filters together with an alternative ground leakage current circuit that bypasses the PE protection wire enables the use of unshielded motor cables without length restrictions, since in this case the motor phase voltages and phase-to-phase voltages are purely sinusoidal.

a)

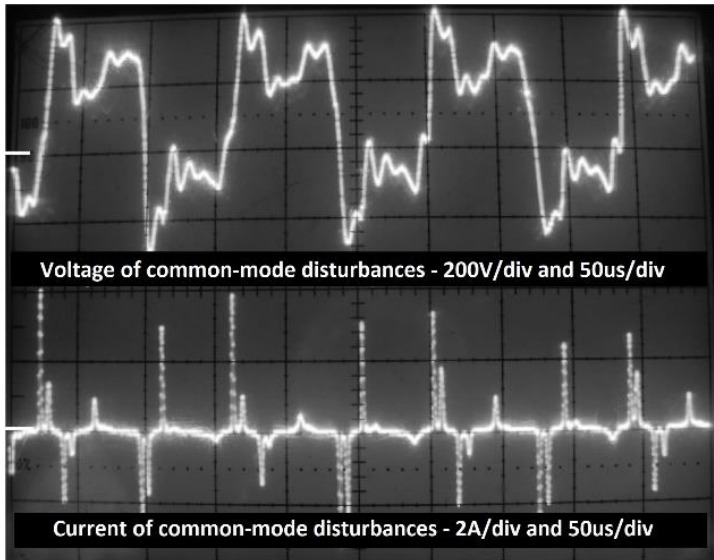

b)

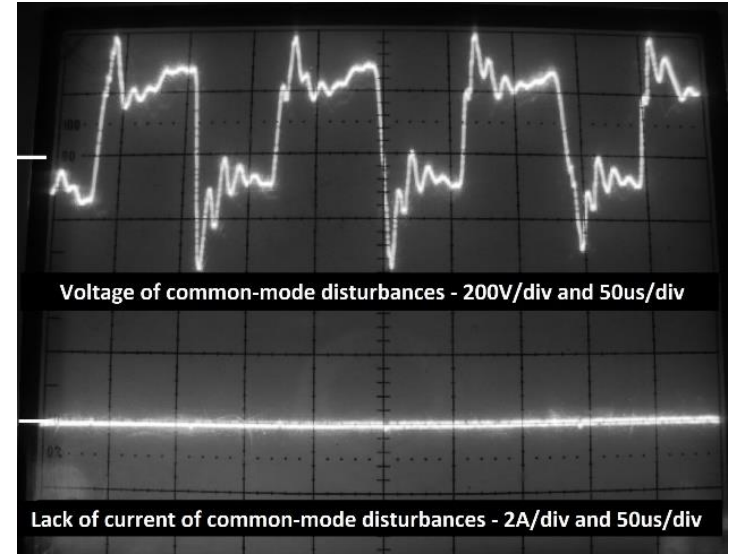

Fig. 8. Voltage of common-mode $\mathrm{u}_{\mathrm{CM}}$ of the frequency converter and ground leakage current $\mathrm{I}_{\mathrm{CM}}$ in the protective PE conductor: a) using the $\mathrm{CM}$ filter (3C capacitive filter ) in power system as presented on Fig. 7a,

b) using a patented DM and CM filter of inverter's disturbance voltages in power system as presented on Fig. 7b. 
Figures $8 \mathrm{a}$ and $8 \mathrm{~b}$ present the results of experimental tests of ground leakage current measured in a protective conductor using the motor power system solution according to figures $7 \mathrm{a}$ and $7 \mathrm{~b}$. Figure $8 \mathrm{a}$ indicates a significant effective value $(0.5 \mathrm{~A})$ of capacitive leakage current Iсм in PE protective conductor using the motor power supply system according to Figure $7 \mathrm{a}$. Figure $8 \mathrm{~b}$ proves the possibility of complete elimination of capacitive leakage current $I_{\mathrm{CM}}$ from the PE conductor using the power supply system according to Figure $7 b$.

\section{Conclusions}

In the absence of effective filtration of ground disturbance currents, which are caused by the inverter's CM voltage in railway traction substations, these currents flow through the transformer causing high frequency disturbances of phase-to-phase voltages. In frequency converter drives, the PWM inverters produce two types of voltage causing disturbances:

- differential-mode voltage (disturbance of phase-tophase voltages),

- common-mode voltage (disturbances of the phase voltages causing the high-frequency flow of the capacitive leakage current)

The DM voltage does not present serious problems for the operation of motors, because the content of higher harmonics at phase-to-phase voltages is greatly reduced through the improved PWM control strategies of the inverter for shaping phase-to-phase voltages of the inverter. The steepness of voltage increase is also limited by the already implemented converters' soft switching of transistors and does not exceed the values allowed by the $700 \mathrm{~V} / \mu \mathrm{s}$ standards (eg. IEC/EN61000-3-4). The insulation of motor windings and technology of its application are improved and there is no visible degradation as a result of rapid changes in the electromagnetic field around the insulation of the stator windings of the motor.

The inverters' common-mode voltage still causes negative effects in the drive system. The impact of this voltage is complex and depends on many factors:

- the motor's power,

- the motor cable lengths,

- the types of motor cables: shielded - unshielded,

- the drive inverter power system: TN - IT

- the control strategies of inverters and the internal filters used by the manufacturers in the frequency converter,

- construction of the drive system: single motor and converter or one higher power converter and many smaller power motors (so-called parallel operation),

- cable trays with motor cables, metal grounded or plastic ungrounded

- the motor operating environment - dry or wet. In railways, with typical applications of auxiliary drives, the phase-to-phase disturbances and ground disturbance do not cause operational problems if these are filtered. There are, however, more complicated cases, for example when powering from one transformer in IT-type power network the multi-motor drive system with individual high power converters. In untypical cases, it is necessary to conduct a detailed analysis of the possibilities for limiting the negative impact of high-frequency ground disturbances caused by the inverters $\mathrm{CM}$ voltages. The $\mathrm{CM}$ voltage $\mathrm{u}_{\mathrm{cm}}$ among others, may cause impermissible deformations of the transformer voltages both in TN and IT network system, and also the damage to the inverter power path, or disrupt data transmission in ICT systems, which are undesirable in rail traffic control systems. Traction inverters with a grounded negative rail must have built-in high-frequency filters of $\mathrm{CM}$ voltages of the inverters on the DC power supply side. Effective filtration of capacitive ground leakage current in the locomotive eliminates its flow through the traction network and traction substation rectifier.

In railway auxiliary drives, e.g. railway switches fitted to inverter drives with an input rectifier, the current harmonics in AC voltage grid must be additionally minimized.

\section{Prądy Uptrwu Doziemnego Generowane NAPIĘCIEM \\ WSPÓLNYM FALOWNIKA MSI}

W kolejowych pojazdach trakcyjnych trójfazowe falowniki MS (Modulacja Szerokości Impulsów) wytwarzają pasożytnicze napięcia różnicowe (Differential Mode Voltage) i wspólne (Common Mode Voltage). Pasożytnicze napięcia są skutkiem ubocznym stosowania modulacji szerokościowej do ksztaltowania napięć międzyfazowych falownika. Wartykuleautorzy przedstawiająopis matematycznynapięc DM oraz CM i przeprowadzają ich analizę widmową. Na podstawie przeprowadzanej analizy autorzy przedstawiają metodę filtraci mbranych harmonicznych napięcia DM i CM dla ograniczania wytwarzanych przez nie prądów pasożytniczych: (DM) międzyfazowych i (CM) - doziemnych. W wyniku badań osiągnięto prawiecatkowitą eliminację pasożytniczego prądu upływu doziemnego zsystemu ochrony przeciwporażeniowejPE.

Stowa kluczowe: dwupoziomowy falownik MSI, napięcia różnicowe napięcie wspólne, modulacja MSI, trójfazowy trakcyjny falownik napięciowy

\section{BiBLIOGRAPHY}

[1] Ambrožič, V., Zajec P. (2016) Električni Servo Pogoni, Slovensko združenje elektroenergetikov CIGRE-CIRED, Ljubljana

[2] Suwankawin S. et al. (2005) Destruction by Charge Current and Its Solution for PWM Inverter Feeding Multiple Motors Through Long Cables. Industry Applications Conference, 2005. Fourtieth IAS Annual Meeting. Conference Record of the 2005

[3] Tallam R. et al. (2006) Failure Mode for AC Drives on High Resistance Grounded System, Applied Power Electronics Conference and Exposition, APEC '06

[4] Yeh Ch., Huang B., Chen K., Fang R., Wang Ch. (2015) Reduction of Common-Mode and Differential-Mode Noises Using TimingOffset Differential Signal, IEEE Transactions on Components, Packaging And Manufacturing Technology, Vol. 5, No. 12, December 2015

[5] Dianguo X., Qiang G., Wei W. (2006) Design of a Passive Filter to Reduce Common-Mode and Differential-Mode Voltage Generated by Voltage-Source PWM Inverter, IECON $2006-32^{\text {nd }}$ Annual Conference on IEEE Industrial Electronics

[6] Sokmen O.G., Alci M. (2018) A Novel Active Element: Fully Differential Voltage Differencing Current Controlled Current Conveyor (FD-VDCCC) and Filter Applications, $5^{\text {th }}$ International Conference on Electrical and Electronics Engineering

[7] Huang J., Shi H. (2015) A Hybrid Filter for the Suppression of Common-Mode Voltage and Differential-Mode Harmonics in Three-Phase Inverters With CPPM, IEEE Transactions on Industrial Electronics Volume 62, Issue 7, July 2015 
[8] Hassan M. S., Shoyama M. (2018) Common-Mode Noise Evaluation Study of Two-Level Voltage Source Inverter using Bus-Clamping Discontinuous PWM Strategies, 2018 IEEE International Telecommunications Energy Conference (INTELEC)

[9] Pairodamonchai P., Sangwongwanich S. (2011) Exact Common Mode and Differential-Mode Equivalent Circuits of Inverters in Motor Drive Systems Taking into Account Input Rectifiers, IEEE PEDS 2011, Singapore, 5-8 December 2011

[10] Li X., Zhang Ch., Chen A., Qin Ch. (2019) Simultaneous CommonMode Resonance Circulating Current and Leakage Current Suppression for Transformerless Three-Level T-Type PV Inverter System, IEEE Transactions on Industrial Electronics, Vol. 66, No. 6 , June 2019

[11] Danfoss: Output Filter Design MG90N402, 2010

[12] Żurek-Mortka M., Szymański J. (2018) Reactive Powe Compensation in a Harmonic Environment, Elektro Info, nr
[13] Kempski A., Smoleński R. (2006) Decomposition of EMI Noise Into Common and Directional Modes in PWM Inverter Drive System. Electrical Power Quality and Utilization, 12 (no. 1)

[14] Szymański J. (2015) The Voltage of Common-Mode Disturbances in Frequency Converters in Railway Systems. Monography, UTH Radom

[15] Szymański J. (2014) The Filter of Common-Mode Voltage of Electronic Frequency Converters Supplied From a Three-Phase, Ungrounded IT Type System. Patent PL No 219221

[16] Holmes D., Lipo T. (2003) Pulse Width Modulation For Power Converters: Principles And Practice. Wiley - IEEE Press

[17] Kempski A. (2005) Electromagnetic Conductive Disturbances in Converter Drive Systems. Monography, Oficyna Wydawnicza Uniwersytetu Zielonogórskiego 